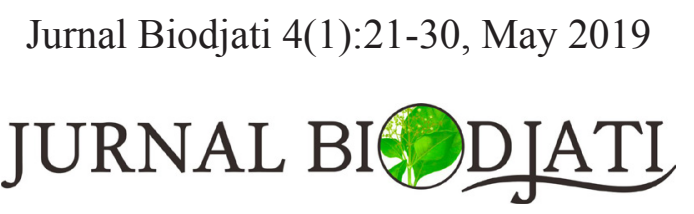

e-ISSN : 2541-4208

p-ISSN : 2548-1606

http://journal.uinsgd.ac.id/index.php/biodjati

\title{
ISOLATION AND DETECTION OF BACTERIOCIN-LIKE INHIBITORY SUBSTANCES-PRODUCING BACTERIA FROM TRADITIONAL FERMENTED MARE'S MILK PRODUCED IN SUMBAWA
}

\author{
Alifia Issabella Mulyawati ${ }^{1}$, Tri Ardyati ${ }^{2}$, Yoga Dwi Jatmiko*3
}

Received : February 15, 2019

Accepted : March 03, 2019

DOI: 10.15575/biodjati.v4i1.4194

${ }^{1,2,3}$ Department of Biology, Faculty of Mathematics and Natural Sciences, Universitas Brawijaya, Malang 65145, telp/fax. 0341-575841

e-mail:

Ialifia.issabella@gmail.com

${ }^{2}$ triardyati@yahoo.com

*3jatmikoyd@ub.ac.id

*Corresponding author
Abstract. Bacteriocin-like inhibitory substances (BLIS) produced by bacteria is a promising future food preservative agent. This study aimed to obtain bacterial strains that can produce broad-spectrum antibacterial agents and identify the best BLIS producer species based on $16 \mathrm{~S}$ rDNA sequences. The bacterial strains were isolated from fermented mare's milk using MRS and M17 agar medium. The isolates then were initially screened based on its antibacterial activity of crude cells against Staphylococcus aureus ATCC 6538. The selected strains were cultured and harvested for its cell-free supernatant (CFS). The pH of CFS was adjusted to 6.5 then used for antibacterial activity assays against ten pathogenic bacteria. Also, the proteinaceous nature of BLIS compound was confirmed by testing with proteinase K. The gDNA of selected isolates was extracted and the $16 \mathrm{~S}$ rDNA was amplified using the polymerase chain reaction method then sequenced. The 16S rDNA sequences of the selected strains were used to identify the species using BLAST nucleotides from NCBI then the phylogenetic trees were constructed. 32 isolates was obtained, but only three isolates (BC9, SB7, and DC12) were selected as a result of antibacterial screening for further assays. The neutralized-CFS (N-CFS) of these isolates exhibited broad-spectrum antibacterial activity. The N-CFS could be assumed as BLIS. The isolate of BC9 was identified as Bacillus amyloliquefaciens strain BC9 that has $99.99 \%$ similarity with B. amyloliquefaciens $K C-1, S B 7$ was Lactobacillus plantarum strain SB7 that has $99.99 \%$ similarity with Lb. plantarum JMC $1149^{T}$, and DC12 was Lactobacillus rhamnosus strain DC12 that has $100 \%$ similarity with Lb. rhamnosus DSM 20021T. Thus, the BLIS produced by those strains is potential for future food and beverages preservations.

Keywords: Bacillus amyloliquefaciens, bacteriocin-like inhibitory substances, fermented mare's milk, Lactobacillus plantarum, Lactobacillus rhamnosus, preservative agents

\section{Citation}

Mulyawati, A. I., Ardyati, T. \& Jatmiko, Y. D. (2019). Isolation and Detection of Bacteriocin-Like Inhibitory Substances-Producing Bacteria from Traditional Fermented Mare's Milk Produced in Sumbawa. Jurnal Biodjati, 4(1), 21-30 


\section{Jurnal Biodjati 4(1):21-30, May 2019 \\ JURNAL BI@DIATI}

http://journal.uinsgd.ac.id/index.php/biodjati

\section{INTRODUCTION}

Fermented mare's milk product originated from West Nusa Tenggara is popular in Indonesia due to its high nutritional content of whey protein, protein fiber, casein, non-nitrogenic protein, lactose, fats, and phospholipids (Malacarne et al., 2002; Pieszka et al., 2015) and its effect on human health especially to cure bronchitis, pneumonia, typhus, and reduce cholesterol level as well as hypertension (Sujaya et al., 2008). The product is prepared by fermenting the fresh mare's milk naturally without the addition of starter cultures. As a consequence, some undesired microbes might be contaminated the final product. In the preliminary study, pathogenic bacteria such as Staphylococcus aureus, Staphylococcus hominis, Staphylococcus epidermidis and Orchrobactrum oryzae were detected in the fermented mare's milk products (Mulyawati et al., 2019). The presence of a range of microbes in this product allows fermentative cultures to establish their niche. Therefore, bacteriocin-producing bacteria are potential to be isolated and then developed as antimicrobial agents.

Fermented mare's milk contains not only high nutrition but also fermentative microbes such as lactic acid bacteria (LAB). The LAB and other bacteria that can be found in fermented mare's milk are assumed to have antibacterial activity due to the production of bacteriocins or bacteriocin-like inhibitory substances (BLIS) (Maurya \& Thakur, 2012). The bacteria are known to produce bacteriocin or BLIS which physiologically has a function to compete with other bacterial cells for nutritional needs. It is already known that bacteriocin or BLIS provides antibacterial activity similar to antibiotics. Since the antibiotics resistance incidence has been increasing recently due to its intensity of bioactivity were active at micro-to-milli molar range, the application of bacteriocins or BLIS as the antibacterial agent exhibit strong activity in the nanomolar range, that causes bacteriocins more potent than antibiotic (Perez et al., 2014; Mathur et al., 2017). Antibiotics generally used for medical purposes only whereas bacteriocins are often applied for either food or clinical purposes. Moreover, bacteriocins relatively do not have toxicity towards eukaryotic cells while antibiotics do (Perez et al., 2014). The exploration of BLISproducing bacteria is necessary to obtain potential strains that can be used as the food and beverages preservative agents.

It is already reported that bacteriocins can inhibit both animal and plant pathogens such as Shiga toxin-producing Escherichia coli, methicillin-resistant Staphylococcus aureus and enterotoxigenic E. coli (Yang et al., 2014). In the previous study, lactic acid bacteria identified as Lactobacillus rhamnosus strain FSMM15, FSMM22 and FSMM26 isolated from fermented mare's milk were potential as probiotic's agents (Shi et al., 2012). Many investigations of LAB species from fermented mare's milk only focused on probiotic properties. Thus, this study aimed to isolate bacteria that can produce broad-spectrum bacteriocin-like inhibitory substances (BLIS) from fermented mare's milk and identify the best BLIS producer strains based on the 16S rDNA sequences.

\section{MATERIALS AND METHODS}

\section{Bacterial Isolation}

The bacteria were isolated from fermented mare's milk samples collected from Bima, Sumbawa and Dompu Regency, Province of West Nusa Tenggara, Indonesia. The milk samples were diluted into a saline solution with 1:9 (v/v) for serial dilutions 


\section{Jurnal Biodjati 4(1):21-30, May 2019 \\ JURNAL BI@DIATI}

http://journal.uinsgd.ac.id/index.php/biodjati

up to $10^{-6}$. Each serial dilution $(0.1 \mathrm{~mL})$ was inoculated into M17 and de Man Rogose Sharpe (MRS) (Merck) agar medium containing $1 \%$ of $\mathrm{CaCO}_{3}$ using spread plate method then incubated for 48 hours at $37^{\circ} \mathrm{C}$. Colonies that produce clear zone during the growth were sub-cultured for further characterization such as Gram-staining and catalase test.

\section{Antibacterial Activity Screening}

Bacterial isolates obtained were screened based on its antibacterial activity against Staphylococcus aureus ATCC 6538. Bacterial isolates were grown in M17 or MRS broth (depend on its originating isolation media) while $S$. aureus was grown in nutrient broth (NB) medium. Both bacteria were incubated for 24 hours at $37^{\circ} \mathrm{C}$. Antibacterial activity of crude bacterial cells was assayed using the disc-diffusion method (Balouiri et al., 2016). $25 \mu \mathrm{L}$ of the bacterial isolate $\left(10^{7}\right.$ cell $/ \mathrm{mL}$ ) was inoculated into the disc with a diameter of $6 \mathrm{~mm}$ (Whatman no.1) then it was spotted onto nutrient agar (NA) medium that already inoculated with $S$. aureus $\left(10^{6}\right.$ cell $/ \mathrm{mL}$ ) and incubated for 24 hours at $37^{\circ} \mathrm{C}$ in triplicates. As the control, blank disc was inoculated with LAB growth medium without bacterial culture. The inhibition zones (mm) produced after incubation were measured as the antibacterial activity. The isolates produced high antibacterial activity were selected for further analysis.

\section{Antibacterial Activity Assay of Bacteriocin- Like Inhibitory Substances}

BLIS of selected isolates were assayed for antibacterial activity. The bacteria were grown in medium M17 or MRS broth, while the pathogenic bacteria were grown in NB medium and incubated for 24 hours at $37^{\circ} \mathrm{C}$. The pathogenic bacteria used for this test were listed in Table 1. The cell culture of BLISproducing bacteria $(15 \mathrm{~mL})$ was centrifuged for $10.000 \times \mathrm{g} ; 4^{\circ} \mathrm{C}$; for 10 minutes to obtain cell-free supernatant (CFS) according to Sharma et al. (2017) with minor modification. The supernatant $\mathrm{pH}$ was adjusted to 6.5 by the addition of $\mathrm{NaOH} 1 \mathrm{~N}$.

The neutralized-CFS was reflected as the BLIS. The antibacterial activity of the BLIS was tested using the disc-diffusion method (Balouiri et al., 2016). As a confirmation of proteinaceous nature of BLIS, the proteinase $\mathrm{K}(1 \mathrm{mg} / \mathrm{mL})$ was added to the BLIS and then applied it for antibacterial activity test. This method was conducted in triplicates. As the control, blank disc was inoculated with LAB growth medium without bacterial cultures.

\section{Identification of Bacteria Based on 16S rDNA Sequences}

The genomic DNA of bacteria was extracted using DNA extraction mini kit (Geneaid) following to the manufacturer's instruction. The DNA was then amplified by PCR using 16S rDNA universal primers i.e., 27f (5'-AGA GTT TGA TCC TGG CTC AG-3') and 1492r (5'-GGT TAC CTT CTT ACG ACT T-3') (Chen et al., 2015). The PCR mixture was containing $25 \mu \mathrm{L}$ GoTaq ${ }^{\circledR}$ Green Master Mix (2x) (Promega), $2 \mu \mathrm{L}$ forward primer $(10 \mathrm{pmol}), 2 \mu \mathrm{L}$ reverse primer (10 pmol), $19 \mu \mathrm{L}$ nuclease-free water and $2 \mu \mathrm{L}$ of DNA template $(40-60 \mu \mathrm{g})$. The PCR reaction was started with initial denaturation at $94^{\circ} \mathrm{C}$ for 5 minutes continued with total 35 cycles of denaturation $\left(94^{\circ} \mathrm{C} ; 30 \mathrm{~s}\right)$, annealing $\left(55^{\circ} \mathrm{C} ; 45 \mathrm{~s}\right)$; elongation $\left(72^{\circ} \mathrm{C} ; 90 \mathrm{~s}\right)$ and a final elongation at $72^{\circ} \mathrm{C}$ for 5 minutes. The PCR products obtained were confirmed qualitatively using DNA electrophoresis in $1.5 \%$ of agarose gel. The amplicons were sent for sequencing at $1^{\text {st }}$ BASE DNA Sequencing Service, Malaysia. The 16S rDNA sequences 


\section{Jurnal Biodjati 4(1):21-30, May 2019 \\ JURNAL BI@DIATI}

http://journal.uinsgd.ac.id/index.php/biodjati

were used to identify the bacteria using BLAST nucleotides from NCBI. The isolates were then compared with the reference sequences obtained from the GenBank database for the phylogeny tree using MEGA 6 software for windows based on the Neighbour-Joining method and Tamura-Nei model.

\section{Statistical Analysis}

All of the data results were statistically analyzed using One Way Analysis of Variance (ANOVA) by SPSS 16.0 software for windows with significant level $p$-value $<0.05$.

\section{RESULTS AND DISCUSSION}

\section{Bacterial Isolation}

Total of bacterial isolates obtained in this study were 32 isolates. All of the isolates were characterized as rod-shaped cells Grampositive bacteria and catalase-negative. Based on these characters, the isolates were presumed as lactic acid bacteria (LAB) group. The LAB group has certain characteristics such as rod or cocci cell, Gram-positive, catalase-negative and produces lactic acid as most of its metabolic products (Ni et al., 2015). The bacteria that included in LAB can ferment the carbohydrates, i.e., L-Arabinose, Galactose, D-Fructose, Rhamnose, Dulcitol, Mannitol, Sorbitol, $\alpha$-Methyl-D-mannoside, $\alpha$-Methyl-D-glucoside, Cellobiose, Maltose, Lactose, Melibiose and Saccharose.

\section{Bacterial Screening Based on Antibacterial Activity}

Total of 32 bacterial isolates were screened based on its antibacterial activity against $S$. aureus ATCC 6538. The result showed that three isolates produce high antibacterial activity against $S$. aureus ATCC 6538 (Figure 1). The isolates from the highest antibacterial activity were DC12 (4.27 \pm 0.42 $\mathrm{mm}), \mathrm{SB} 7(4.19 \pm 0.16 \mathrm{~mm})$ and BC9 (4.17 $\pm 0.81 \mathrm{~mm}$ ), respectively $(\mathrm{p}<0.05)$ (Figure 1). Based on this result, bacterial isolates of DC12, SB7 and BC9 were selected for further analysis.

The screening section was done using $S$. aureus ATCC 6538 as the pathogenic bacteria indicator. This species was selected as the indicator on this screening because $S$. aureus is the pathogenic bacteria that most often found contaminated during the manufacturing of milk product (Basanisi et al., 2016; Pappa et al., 2017). In the previous study, some Staphylococcus species, i.e., S. aureus, $S$. hominis, $S$. epidermidis have been isolated from fermented mare's milk product derived from Dompu and Bima Regency, West Nusa Tenggara, Indonesia (Mulyawati et al., 2019).

\section{Antibacterial Activity of Bacteriocin-Like Inhibitory Substances}

The selected isolates were assayed for its antibacterial activity against ten different pathogenic bacteria (Table 1). The result showed that isolate BC9 could inhibit the growth of all the pathogenic bacteria species used in this test. The highest inhibition zone produced by BC9 was $3.27 \pm 0.74 \mathrm{~mm}$ against Orchrobactrum oryzae strain SC2, while the lowest inhibition found on the growth of $\mathrm{S}$. hominis strain BB1 (Figure 2). Isolate SB7 and DC12 produced inhibition zones against the growth of nine pathogenic bacteria species, but it could not inhibit the growth of Bacillus cereus. The highest inhibition zone produced by SB7 and DC12 was found against S. aureus DC8 with the inhibition zone was $2.72 \pm 0.32$ $\mathrm{mm}$ and $2.45 \pm 0.34 \mathrm{~mm}(\mathrm{p}<0.05)$ (Figure 2). The neutralized-CFS of three selected isolates was categorized as bacteriocins because the antibacterial activity was not exhibited after treating with proteinase $\mathrm{K}$.

The BLIS of selected isolates showed 


\section{Jurnal Biodjati 4(1):21-30, May 2019 \\ JURNAL BIDDJATI}

http://journal.uinsgd.ac.id/index.php/biodjati

different antibacterial activity spectrum against the pathogenic bacteria tested. The BLIS obtained from BC9 was able to inhibit the growth of all the pathogenic bacteria tested, while SB7 and DC12 could not inhibit the growth of Bacillus cereus. However, the
BLIS of both isolates can be categorized as the broad-spectrum BLIS. The bacteriocin activity against several Gram-negative and Gram-positive bacteria indicated that it produced bactericidal protein exhibits a broad antimicrobial spectrum (Lim et al., 2016).

Table 1 . The pathogenic bacteria species used for antibacterial activity assay

\begin{tabular}{cccc}
\hline No. & Species & Gram & Sources \\
\hline 1. & Staphylococcus aureus strain DC8 & Positive & \\
2. & Staphylococcus epidermidis strain DC11 & Positive & Fermented mare's milk \\
3. & Staphylococcus hominis strain BB1 & Positive & \\
4. & Orchrobactrum oryzae strain SC2 & Negative & \\
5. & Staphylococcus aureus strain ATCC 6538 & Positive & Collection of \\
6. & Escherichia coli strain ATCC 25922 & Negative & Microbiology \\
7. & Bacillus cereus & Positive & Laboratory, \\
8. & Salmonella enterica sv. typhimurium strain ATCC 14028 & Negative & Department of \\
9. & Pseudomonas aeruginosa strain ATCC 9072 & Negative & Biology, Universitas \\
10. & Bacillus anthrophaeus strain ATCC 9372 & Positive & Brawijaya \\
\hline
\end{tabular}

\section{Identification of Bacteria Based on $16 \mathrm{~S}$ rDNA Sequences}

The 16S rDNA from the gDNA of selected isolates were amplified, with the size was around $1500 \mathrm{bp}$ (Figure 3). Isolate of BC9 was identified as Bacillus amyloliquefaciens strain BC9 which has $99.99 \%$ similarity with $B$. amyloliquefaciens strain $\mathrm{KC}-1$ (Figure 4a). The isolate of SB7 was identified as Lactobacillus plantarum strain SB7 which has $99.99 \%$ similarity with $L b$. plantarum strain JCM $1149^{\mathrm{T}}$ (Figure 4b). Isolate of DC12 was identified as Lactobacillus rhamnosus strain DC12 which has $100 \%$ similarity with Lb.

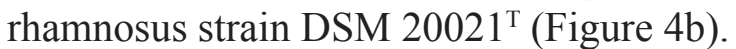

Bacillus amyloliquefaciens strain BC9 isolated from mare's milk product originated from Bima Regency, West Nusa Tenggara, Indonesia. As mentioned previously, BC9 could produce the bactericidal proteins known as bacteriocin with broad-spectrum activity. It was reported on several studies that Bacillus group are recognized as prospective producers of antimicrobial substances, i.e., bacteriocins, peptide and lipopeptide antibiotics (Lim et al., 2016). The bacteriocins produced by the Jurnal Biodjati 4(1):21-30 May 2019
Bacillus group are considered as the second most important bacteriocin after LAB group (Abriouel et al., 2011; Lim et al., 2016). Bacteriocins Class I (lantibiotics) produced by $B$. amyloliquefaciens strain RX7 have broad-spectrum inhibitory properties with thermostability and tolerance towards a broad range of $\mathrm{pH}$ and various solvents (Lim et al., 2016). Several studies reported that Bacillus amyloliquefaciens has antimicrobial activity against Clostridium perfringens (Lei et al., 2015), Listeria monocytogenes, B. cereus, $S$. aureus, E. coli, P. aeruginosa, Salmonella enteritidis and Salmonella gallinarum (Hanafy et al., 2016; Lim et al., 2016). Bacillus amyloliquefaciens was also reported as a potential feed additive of broiler diets due to its probiotic properties (Ahmed et al., 2014).

The isolate of BC9 was isolated from fermented mare's milk using the LAB's growth medium. Thus, the BC9 has initially assumed to be belongs to the LAB group. However, the 16S rDNA sequences analysis was confirmed that BC9 isolate was Bacillus amyloliquefaciens (Bacillus group). Similarly, Bacillus amyloliquefaciens has also been 


\section{Jurnal Biodjati 4(1):21-30, May 2019 \\ JURNAL BIDDJATI}

http://journal.uinsgd.ac.id/index.php/biodjati

isolated from Eleven Aloqt (traditional crusty dried processed goat milk) using MRS agar (Hanafy et al., 2016). Bacillus sp. can produce L-lactic acid in anaerobic and aerobically culture (Ohara \& Yahata, 1996), as a results the clear zone was observed on MRS agar containing $\mathrm{CaCO}_{3}$. Thus, this is not the first finding of $B$. amyloliquefaciens from milk products. In this study, catalase test result of B. amyloliquefaciens BC9 was negative. However, some of Bacillus was reported as catalase-negative, i.e., the Bacillus polymyxa (Abiola \& Oyetayo, 2016), generally, B. amyloliquefaciens strains are catalase-positive (Singh et al., 2013; Elanchezhiyan et al., 2018). Over-reliance on the catalase-test can result in misidentification, particularly might be interfered by the culture age and stability of the reagent. Moreover, it has been also suggested that characterization of LAB based on genotypic characters is more accurate than phenotypic characters (Mulyawati etal., 2019).

The isolate of SB7 was identified as Lb. plantarum strain SB7. This strain produces broad-spectrum bacteriocin-like inhibitory substances due to its ability to inhibit the growth of the nine pathogenic bacteria tested in this study. It was reported that $L b$. plantarum can inhibit the growth of Staphylococcus aureus (Song et al., 2014) and the beverage-spoilage bacterium Alicyclobacillus acidoterrestris (Borrero et al., 2018). Also, Lb. plantarum strain 163 was reported to produce bacteriocin (Plantaricin 163) which exhibit the broad-spectrum antibacterial activity against LAB group and other tested Gram-positive and Gram-negative bacteria (Hu et al., 2013). Similar result was also observed on DC12 isolate that has been identified as Lactobacillus rhamnosus DC12. Thus, antibacterial activity of this strain was considered as broad-spectrum. However, this strain could not inhibit the growth of $B$. cereus. In the previous study, Lb. rhamnosus IMC 501 could not inhibit the growth of $B$. cereus DSM 345 but could inhibit $S$. aureus ATCC 25923, E. coli DSM 1103 and Candida albicans ATCC 10261 by modified cross-streak method (Coman et al., 2014). Lactobacillus rhamnosus CJNU 0519 isolated from a natural cheese produced bacteriocin (Rhamnocin 519) that has a narrow antimicrobial activity which only actively against $L b$. acidophilus, $L$. monocytogenes and $S$. aureus among other tested bacterial and yeast strains (Jeong \& Moon, 2015).

In conclusion, bacterial isolates of $\mathrm{BC} 9, \mathrm{SB} 7$ and DC12 isolated from traditional fermented mare's milk product produced broad-spectrum BLIS and identified as Bacillus amyloliquefaciens strain BC9, Lactobacillus plantarum strain SB7 and Lactobacillus rhamnosus strain DC12, respectively. These strains are a promising producer of antimicrobial compounds for the future preservative agents on food and beverages. However, further research related to purification and characterization of BLIS produced by those strains is still required. 


\section{JURNAL BIDDJATI}

http://journal.uinsgd.ac.id/index.php/biodjati

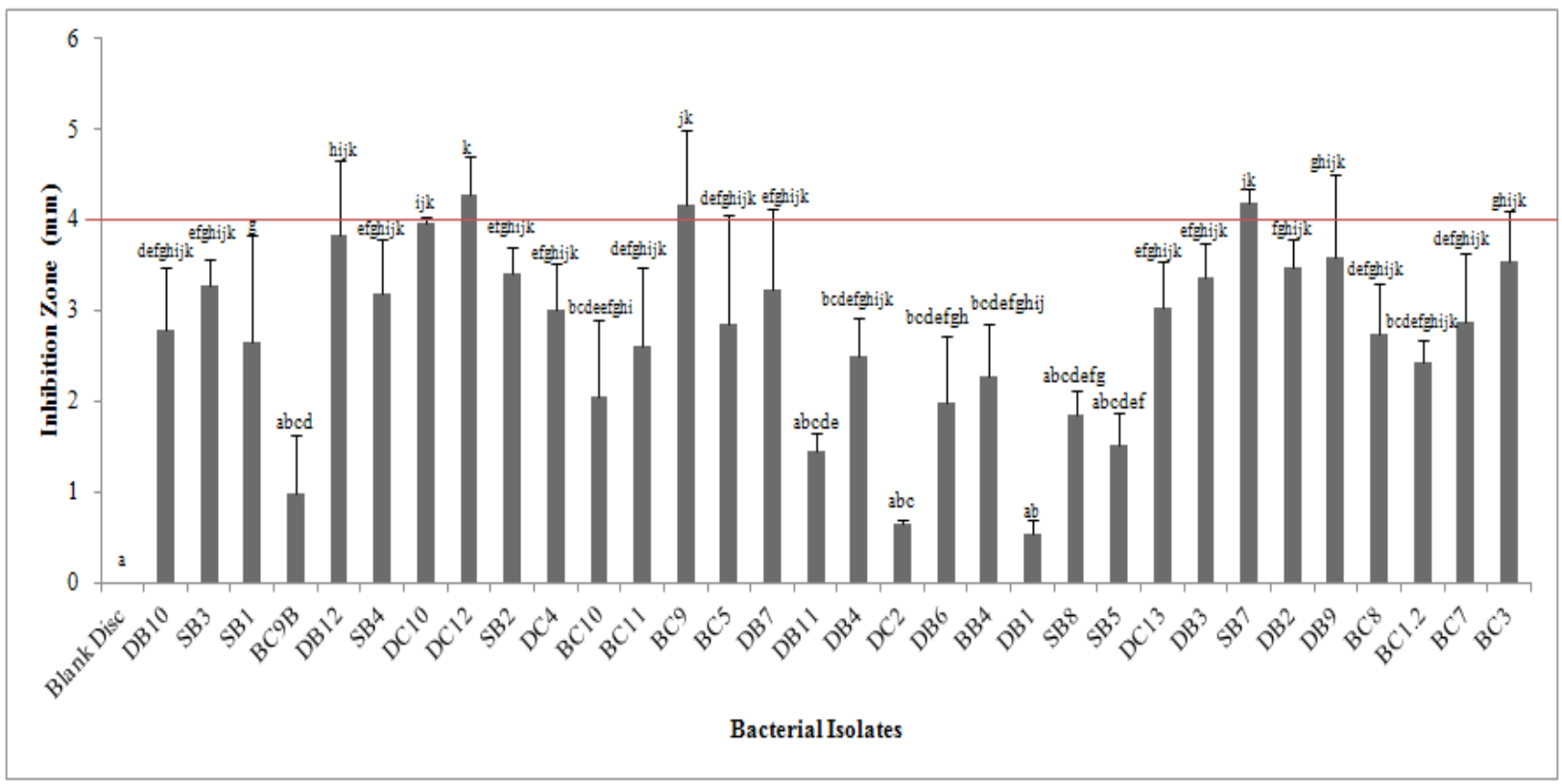

Figure 1. The antibacterial activity using crude cells of isolated bacteria against $S$. aureus ATCC 6538 . The selected strains were based on the inhibition zone of more than $4 \mathrm{~mm}$. Data are expressed as means \pm standard deviation of the mean of three replicates. Bar values not sharing the same letter are significantly differences $(\mathrm{p}<0.05)$.

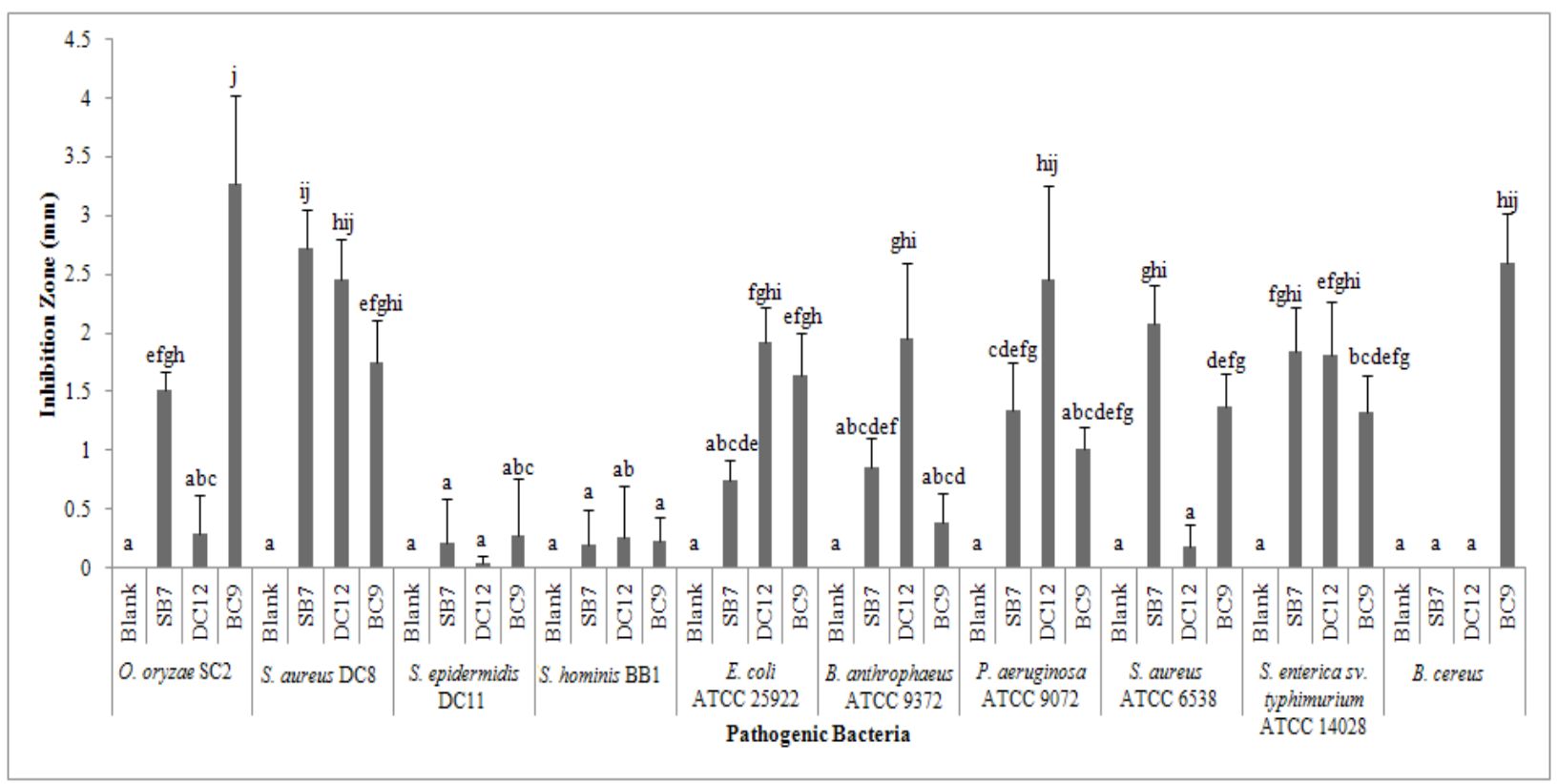

Figure 2. The antibacterial activity of BLIS produced by Lb. plantarum SB7, Lb. rhamnosus DC12, and B. amyloliquefaciens BC9 against pathogenic bacteria. Data are expressed as means \pm standard deviation of the mean of three replicates. Bar values not sharing the same letter are significantly differences $(\mathrm{p}<0.05)$. 


\section{Jurnal Biodjati 4(1):21-30, May 2019 \\ JURNAL BI@DIATI}

http://journal.uinsgd.ac.id/index.php/biodjati

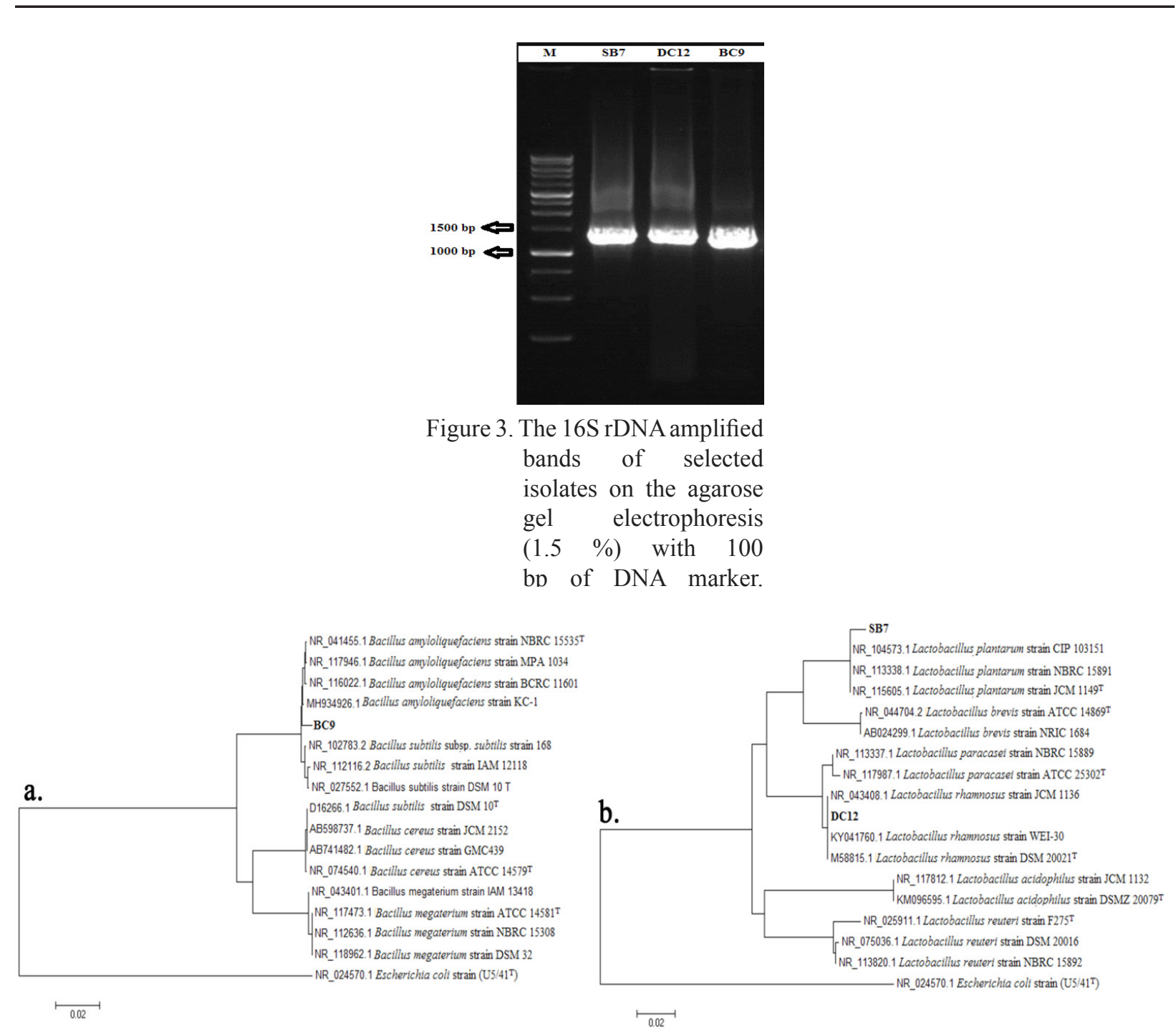

Figure 4. The phylogenetic tree constructed using MEGA 6 software by neighbour-joining method (1000x bootstraps) for 16S rDNA sequences of (a) Bacillus amyloliquefaciens strain BC9 and (b) Lactobacillus plantarum strain SB7 and Lactobacillus rhamnosus strain DC12.

\section{ACKNOWLEDGMENTS}

This work was financially supported by DPP/SPP Research Grant 2018, Faculty of Mathematics and Natural Sciences, Universitas Brawijaya.

\section{REFERENCES}

Abiola, C. \& Oyetayo, V. O. (2016). Isolation and Biochemical Characterization of Microorganisms Associated with the
Fermentation of Kersting's groundnut (Macrotyloma geocarpum). Research Journal of Microbiology, 11, 47-55.

Abriouel, H., Franz, C. M. A. P., Ben Omar, N. \& Gálvez, A. (2011). Diversity and Applications of Bacillus Bacteriocins. FEMS Microbiology Reviews, 35(1), 201-232.

Ahmed, S. T., Islam, M. M., Mun, H.-S., Sim, H.-J., Kim, Y.-J. \& Yang, C.-J. (2014). Effects of Bacillus amyloliquefaciens as a Probiotic strain on growth 


\section{Jurnal Biodjati 4(1):21-30, May 2019 \\ JURNAL BIDDJATI}

http://journal.uinsgd.ac.id/index.php/biodjati

Performance, Cecal Microflora, and Fecal Noxious Gas Emissions of Broiler Chickens. Poultry Science, 93(8), 1963-1971.

Balouiri, M., Sadiki, M. \& Ibnsouda, S. K. (2016). Methods for In Vitro Evaluating Antimicrobial Activity: A Review. Journal of Pharmaceutical Analysis, 6(2), 71-79.

Basanisi, M. G., Nobili, G., La Bella, G., Russo, R., Spano, G., Normanno, G. \& La Salandra, G. (2016). Molecular Characterization of Staphylococcus aureus Isolated from Sheep and Goat Cheeses in Southern Italy. Small Ruminant Research, 135, 17-19.

Borrero, J., Kelly, E., O'Connor, P. M., Kelleher, P., Scully, C., Cotter, P. D. \& Sinderen, D. Van. (2018). Plantaricyclin A, a Novel Circular Bacteriocin Produced by Lactobacillus plantarum NI326: Purification, Characterization, and Heterologous Production. Appl. Environ. Microbiol, 84(1), 01-17.

Chen, Y.-L., Lee, C.-C., Lin, Y.-L., Yin, K.-M., Ho, C.-L. \& Liu, T. (2015). Obtaining Long 16S rDNA Sequences Using Multiple Primers and its Application on Dioxin-Containing Samples. BMC Bioinformatics, 16(18), S13.

Coman, M. M., Verdenelli, M. C., Cecchini, C., Silvi, S., Orpianesi, C., Boyko, N. \& Cresci, A. (2014). In Vitro Evaluation of Antimicrobial Activity of Lactobacillus rhamnosus IMC 501®, Lactobacillus paracasei IMC 502® and SYNBIO ${ }^{\circledR}$ Against Pathogens. Journal of Applied Microbiology, 117(2), 518-527.

Elanchezhiyan, K., Keerthana, U., Nagendran K., Prabhukarthikeyan, S. R., Prabakar, K., Raguchander, T. \& Karthikeyan, G. (2018). Multifaceted Benefits of Bacillus amyloliquefaciens Strain FBZ24 in the
Management of Wilt Disease in Tomato Caused by Fusarium oxysporum f. sp. lycopersici. Physiological and Molecular plant Pathology, 103, 92-101.

Hanafy, A. M., Al-Mutairi, A. A., Al-Reedy, R. M. \& Al-Garni, S. M. (2016). Phylogenetic Affiliations of Bacillus amyloliquefaciens Isolates Produced by a Bacteriocin-Like Substance in Goat Milk. Journal of Taibah University for Science, 10(4), 631-641.

Hu, M., Zhao, H., Zhang, C., Yu, J. \& Lu, Z. (2013). Purification and Characterization of Plantaricin 163, a Novel Bacteriocin Produced by Lactobacillus plantarum 163 Isolated from Traditional Chinese Fermented Vegetables. Journal of Agricultural and Food Chemistry, 61(47).

Jeong, Y.-J. \& Moon, G.-S. (2015). Antilisterial Bacteriocin from Lactobacillus rhamnosus CJNU 0519 Presenting a Narrow Antimicrobial Spectrum. Korean Journal for Food Science of Animal Resources, 35(1), 137-142.

Lei, X., Piao, X., Ru, Y., Zhang, H., Péron, A. \& Zhang, H. (2015). Effect of Bacillus amyloliquefaciens-based Direct-fed Microbial on Performance, Nutrient Utilization, Intestinal Morphology and Cecal Microflora in Broiler Chickens. Asian-Australasian Journal of Animal Sciences, 28(2), 239-246.

Lim, K. B., Balolong, M. P., Kim, S. H., Oh, J. K., Lee, J. Y. \& Kang, D.-K. (2016). Isolation and Characterization of a Broad Spectrum Bacteriocin from Bacillus amyloliquefaciens RX7. BioMed Research International, 2016.

Malacarne, M., Martuzzi, F., Summer, A. \& Mariani, P. (2002). Protein and fat Composition of Mare's Milk: Some Nutritional Remarks with Reference to 


\section{Jurnal Biodjati 4(1):21-30, May 2019 \\ JURNAL BI@DIATI}

http://journal.uinsgd.ac.id/index.php/biodjati

Human and Cow's Milk. International Dairy Journal, 12(11), 869-877.

Mathur, H., Field, D., Rea, M. C., Cotter, P. D., Hill, C. \& Ross, R. P. (2017). Bacteriocin-Antimicrobial Synergy: A Medical and Food Perspective. Frontiers in Microbiology, 8, 1205.

Maurya, A. P. \& Thakur, R. L. (2012). Inhibition Spectrum, Purification and Characterization of Bacteriocin from Leuconostoc NT-1. Current Science, 103(12), 1405-1407.

Mulyawati, A. I., Jatmiko, Y. D., Mustafa, I., Ardyati, T. \& Suharjono. (2019). Diversity of Lactic Acid Bacteria Isolated from Fermented Mare's Milk Products Based on PCR-RFLP Analysis. IOP Conf. Ser.: Earth Environ. Sci., 230, 012104.

Ni, K., Wang, Y., Li, D., Cai, Y. \& Pang, H. (2015). Characterization, Identification and Application of Lactic Acid Bacteria Isolated from Forage Paddy Rice Silage. PLoS ONE, 10(3), e0121967.

Ohara, H. \& Yahata, M. (1996). L-Lactic acid production by Bacillus sp. in Anaerobic and Aerobic Culture. Journal of Fermentation and Boengineering, 81(3), 272-274.

Pappa, E. C., Bontinis, T. G., Tasioula-Margari, M. \& Samelis, J. (2017). Microbial Quality of and Biochemical Changes in Fresh Soft, Acid-Curd Xinotyri Cheese Made from Raw or Pasteurized Goat's Milk. Food Technology and Biotechnology, 55(4), 496-510.

Perez, R. H., Zendo, T. \& Sonomoto, K. (2014). Novel Bacteriocins from Lactic Acid Bacteria (LAB): Various Structures and Applications. Microbial Cell Factories, 13(1), S3.

Pieszka, M., Łuszczyński, J., Zamachowska, M., Augustyn, R., Długosz, B. \&
Hędrzak, M. (2015). Is Mare Milk an Appropriate Food for People? - A Review. Annals of Animal Science, 16. Sharma, C., Singh, B. P., Thakur, N., Gulati, S., Gupta, S., Mishra, S. K. \& Panwar, H. (2017). Antibacterial Effects of Lactobacillus IsolatesofCurdandHuman Milk Origin Against Food-Borne and Human Pathogens. 3 Biotech, 7(1), 31.

Shi, T., Nishiyama, K., Nakamata, K., Aryantini, N. P. D., Mikumo, D., Oda, Y. \& Fukuda, K. (2012). Isolation of Potential Probiotic Lactobacillus rhamnosus Strains from Traditional Fermented Mare Milk Produced in Sumbawa Island of Indonesia. Bioscience, Biotechnology, and Biochemistry, 76(10), 1897-1903.

Singh, S., Moholkar, V. S. \& Goyal, A. (2013). Isolation, Identification, and Characterization of a Cellulolytic Bacillus amyloliquefaciens strain SS35 from Rhinoceros Dung. Hindawi Publishin Corporation ISRN Microbiology, 728134.

Song, D.-F., Zhu, M.-Y. \& Gu, Q. (2014). Purification and Characterization of Plantaricin ZJ5, a New Bacteriocin Produced by Lactobacillus plantarum ZJ5. PLOS ONE, 9(8), e105549.

Sujaya, N., Ramona, Y., Widarini, N. P., Suariani, N. P., Dwipayanti, N. M. U., Nocianitri, K. A. \& Nursini, N. W. (2008). Characterization of Lactic Acid Bacteria Isolated from Sumbawa Mare Milk. Jurnal Veteriner, 9(2).

Yang, S.-C., Lin, C.-H., Sung, C. T. \& Fang, J.-Y. (2014). Antibacterial Activities of Bacteriocins: Application in Foods and Pharmaceuticals. Frontiers in Microbiology, 5(241). 